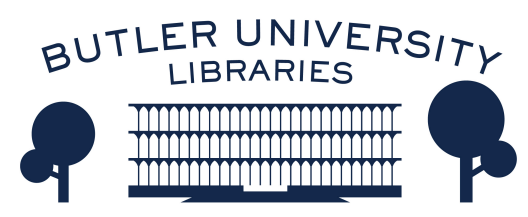

Journal of Hindu-Christian Studies

Volume 14

Article 5

January 2001

\title{
Grounds for Mutual Growth
}

C. Murray Rogers

Follow this and additional works at: https://digitalcommons.butler.edu/jhcs

Part of the Religion Commons

\section{Recommended Citation}

Rogers, C. Murray (2001) "Grounds for Mutual Growth," Journal of Hindu-Christian Studies: Vol. 14, Article 5.

Available at: https://doi.org/10.7825/2164-6279.1248

The Journal of Hindu-Christian Studies is a publication of the Society for Hindu-Christian Studies. The digital version is made available by Digital Commons @ Butler University. For questions about the Journal or the Society, please contact cbauman@butler.edu. For more information about Digital Commons @ Butler University, please contact digitalscholarship@butler.edu. 


\title{
Grounds for Mutual Growth
}

\author{
C. Murray Rogers \\ Oxford
}

I was asked to share the way in which my view of Hindu-Christian dialogue has changed over the years and it is a joy to try to do so. Forgive me if, instead of a formal article, I write in a more personal vein as, maybe, a swansong, a last testimony to what has become more and more central in my life. After all at $83 \mathrm{I}$ am likely very soon to be singing my last song!

Naturally enough since moving to England after 52 years lived so largely in Asia and especially in India, I have less "official" dialogue with Hindu friends but that is no hindrance. What began as an academic exercise becomes one's existence. Notions are left behind and it is a question of everyday life, even of survival. I have only to go down any road here in East Oxford, or go to the Asian Cultural Club to which I belong, and I meet from India or elsewhere both Hindus and Muslims - not to mention the unique smells of their restaurants in Cowley Road! Their way, their presuppositions and perceptions, their scriptures and prayers, have reached so far inside me, into my mind and heart, that they are, I rather think, inseparable from "the little me". This is the gift of friendship and every year, certainly every ten years, since physically leaving the ashram in Kareli village, U.P., India, the distance between my close Hindu friends and myself, a disciple of Christ, grows less. We belong to one another; we see no need and have no intention of "becoming" the other; we even wonder what "other" means in the depth of our human and spiritual experience.

What happens to each of us is mutual enrichment, augmentation. I used to think and to argue that becoming in any way a Hindu, sharing their presuppositions, would be a loss, almost a disaster, to me a Christian! Now, still in the same life on this plane, I sense that their Hindu way and experience is an immeasurable gift to me; they have added in countless ways to my life as a Christian human being. On the level of the mental, the conceptual, a gulf often remains, but deeper, when words fail, when in friendship and life we find ourselves to be as thankful for what we cannot fathom as for what we can, we find a positive strength and grounds for mutual growth. More sharing of silence between us, the end of defensiveness between us and our steady movement away from duality and any interest in comparison become a revelation of how far nonseparation and unity are built into life, into our shared human nature.

I wonder how long it will remain the perceived obligation of Christian people to engage in evangelism, if by this word one means to speak and act so as to encourage others to change their religion, be baptised and be officially named as Christian people, members of an organised church? Do we not all need to be converted, not to a different religious affiliation but, infinity more deeply, in our inner being, to the spiritual way that we have received at birth? This does not, for one moment, mean that those of us who owe our life, our salvation and joy to the living and resurrected Lord Christ, should, or indeed could keep silent about the One to whom we owe so much. Our great hope is that by our life and word our very existence may point to him, to his love and presence.

My reading of the Gospel makes it very far from evident that Jesus had any intention of beginning a new religion or such institutions as present structures of 
power/control, prestige and money that are called churches. Am I the only one who would be appalled if the Dalai Lama or a saint of any spiritual way were to become a Roman Catholic, an Anglican, a Baptist or a member of any other Christian religious body? No, where the fruits of the Spirit, the fruits which were to be found so superlatively in Jesus himself, and described by Paul in his letter to the Galatians (5:2223), are to be found, there for me is the Catholic Church, the universal family of God. In truth humanity is the Church, coming into being, beyond every religious grouping. When Raimundo Panikker says: "In Christ there is neither Hindu or Christian" my mind and heart echo his statement.

Often most painfully - anguish was the word often on Swami Abhishiktanandaji's (Dom Le Saux) lips - our traditional mental categories are shattered and what Teilhard de Chardin called "the dimensions of God" are immeasurably widened. One's old intellectual position, described so accurately in Psalm 53 is blown away!

"They think that they know; their minds move on the surface of things. They don't perceive the deep patterns or understand who they are"

(Stephen Mitchell's version)

Then, when the old paradigm has "exploded", often in friendship with another person of faith, of "another" spiritual family, or indeed of no spiritual family, I am thankfully constrained to recognise it as a grace bringing joy and freedom from the narrowness in which we are so tragically educated in our so-called monotheistic families. This narrowness is always a short step from an intolerance and violence with which history is full, not least in our own time.

This blessed and non-violent revolution in mental and spiritual outlook, owed in my own case to the friendship, patience and love of Hindu, Buddhist and Muslim friends, has left me with a respect and love for their scriptures and for the prayers of their spiritual masters. It was away back in the 1960's that Swami Abhishiktananda, himself a Roman Catholic monk and priest, led us sensitively and fearlessly to taste the marvellous gift of the Vedas, the Upanishad and the Gita, and to pray in our own "Christian" hearts prayers of the Sukla Yajur Veda, of Sri Sankaracarya, of Sri Yamunacarya, of Tulsidas, of the Skandapurana and of a host of others. A taste of such prayers follows:

O Lord, thou art on the sandbanks as well as in the midst of the current; I bow to thee. Thou art in the little pebbles as well as in the calm expanse of the sea; I bow to thee. $O$ allpervading Lord, thou art in the barren soil and in crowded places, I bow to thee.

Sukla Yajur Veda xv1, 43

Thou art father, mother, husband and son. Thou art dear friend, relative and teacher, and the goal of the universe. I am thine own, thy servant and attendant. Thou art my only refuge. I have taken refuge in thee, and verily, $O$ Lord, my burden rests wholly on thee. Sri Yamunacarya: Stotraratna 60

These do not for a minute take the place, either in our common worship or in our personal prayer, of the Bible and of the precious heritage of prayer in our Christian tradition. The one and the other flow together and increase greatly our joy and our understanding. In our daily celebration of the Eucharist, the high point of our life and work each day, it would now be unthinkable to omit a reading from Eastern scriptures, often with a commentary such as that of Eknath Easwaran, before we read from the Gospels in the New Testament of the Bible. The gifts of God are unbelievably lavish!

The question and challenge of interfaith dialogue confronts us in the West in many forms. Lately the intensely Hindu happening of the Maha Kumbh Mela in Allahabad has been brought vividly into homes in Britain through daily comments and photographs on radio and TV and in the press. For me 
personally it has been a strong reminder of changes in my own attitude. Just over 50 years ago I was on the staff of a Christian College in Allahabad, which was situated some two miles up the Yamuna river from its sacred confluence with the river Ganga and the mythical river, the Saraswati. It was then that I went as a spectator and mingled with the vast Kumbh Mela crowds, with the millions of people as they bathed in the river on the auspicious day and at the auspicious hour, led by the sages, holy men, ascetics, nagas and a host of simple people from the whole country. At that time it appeared to me to be a vast fair, am irrational explosion of religious fervour, a display of the human psyche when Hindu human beings in their millions jostle together within an area of six square miles to bathe amid a furore of noise. Now sadly superficial and false were my impressions at that time!

Owing to the great changes that have taken place over the years, in myself and in my relationship with Hindu friends and with the sanatana dharma, this year's great Kumbh Mela of some 70-90 million people (cp. this visit of the present Pope to Manilla in 1995 of 5 million) brought forth to my surprise an extraordinarily different reaction.

The same vast and dense crowds of human beings were to be seen as fifty years ago but infinitely more numerous, the great organisational work of building a town, Kumbh Nagar, which will last for six weeks and house the millions of tents, not to mention the many miles of roads, the whole only to disappear within a few weeks to make way once more for sand and water...Day and most of the night religious music is played on loud speakers and an endless variety of speakers, each preaching his own version of the good news of salvation, in ways that are often mutually contradictory according to our Western understanding. The sages and intellectual and spiritual giants, members of ashrams and matts coming from all over the subcontinent, sharing the same suffering and discomfort as the innumerable illiterate and poor majority of the Hindu family, and all together to celebrate faith. It is surely humanity's greatest festival of faith, the power of myth to bring unity out of the greatest intellectual, spiritual, social and educational diversity. There is in the air a glad willingness to live in uncertainty, even with the prospect of death, and an unspoken readiness to leave the others "space" and freedom to be utterly different from oneself; the word heretic is unknown! There is in that Kumbh world no claim to monopoly of truth, but a clear call from all, and to all, in their immense variety of expressions of the sanatana dharma, to celebrate faith, a festival of faith whose high moment of ecstasy is the plunge by each one into the sacred Ganga, the river of grace ever flowing from the silence of eternal snows to the ocean of God's love.

All this and more confronts me, a Christian, with many questions, with serious criticism of my own religious world and the self-understanding of us Christians. Is it indeed another example of the saying that "nothing is itself without everything else"? The fruits of interfaith life are, I am convinced, more essential than was ever conceived some years ago.

The Kumbh Mela experience leaves us, at least, with these insistent questions: Why is it that Christians search for unity so exclusively in intellectual and theological agreement on doctrinal and dogmatic matters? Why is it that hierarchy is so central to our life and to our conception of unity? Why is it that the "united" churches of south and north India, the fruits of many years of prayer and serious discussion of doctrines and order, shows signs, many would agree, of results which are singularly disappointing? Are we being driven to the conclusion that, while our Christian leaders cling tenaciously to our intellectual structures to secure our very limited unity, our Hindu contemporaries entrust themselves to the Atman, the Spirit, and receive an infinitely greater measure of unity in unlimited diversity?

Until such questions find some answer a Christian festival of faith, parallel to the Kumbh Mela experience, will remain inconceivable because our "Christian" 
disagreements on the intellectual and historical levels, not to mention the never very distant denominational vested interests and pride, would be insurmountable handicaps to such a Christian celebration. Dare we, who claim to have the mind of Christ, renounce our claims to the monopoly of faith, our claims of spiritual superiority and our inherent suspicion of uncertainty? How is it possible that we live, one might say, from our disunity while our Hindu brothers and sisters at the Kumbh Mela, show, for all the world to see, that their vast differences among themselves are not invincible barriers to celebrating faith, in fact that their great variety of spiritual and intellectual expressions is their glory? So many questions awaiting an answer, in life and experiences, and; later, in thought.

We remember, I am certain, Varuna's final word to his son Brigu in the Taittiriya Upanishad (III.6.1 Mascaro)

"For from joy all beings have come, by joy they all live, and unto joy they all return."

Isn't our whole search driven by joy? Joy together. 